\title{
NOTES ON RED SPRUCE ${ }^{1}$
}

\author{
By C. C. Heimburger
}

\author{
Dominion Forest Service, Ottawa, Canada
}

\section{DISTRIBUTION}

THIS species was found in Canada at the south edge of the Laurentides Park near Quebec City, and at the Valcartier Forest Experiment Station, and on the Lake Edward Forestry Experimental area. Last winter (1937) it was discovered in the region of the lower Gatineau river and subsequently on the lands of the Seigniory Club near Montebello, P.Q., in isolated stands. In the autumn of 1938 red spruce was observed occurring frequently on the Quebec side of the Ottawa river just east of Hawkesbury, Ont. This last occurrence most probably marks the westernmost point of a continuous range of this species to the north of the St. Lawrence valley, within the Great Lakes-St. Lawrence Forest Region ${ }^{2}$. Recent observations by the Faculty of Forestry, University of Toronto, indicate the presence of isolated stands of red spruce in Haliburton county, Ont. All the occurrences of red spruce to the north of the St. Lawrence valley are confined to the east portion of the Algonquin-Laurentides section of the above region; in no case does this species enter a boreal forest as it does at higher elevations within its range in the United States. This is a distinct natural handicap to Canadian forestry, in that this valuable softwood species is lacking in the forests of northern Quebec and Ontario, for some as yet unknown reason. The St. Lawrence Valley constitutes a distinct gap in the range of red spruce in Canada, separating it into a small northern part and a much larger southern part merging with the range of this species in New England. This southern part comprises the Eastern Townships of Quebec and a large part of the Maritime Provinces.

On the journey southeast from Montreal, red spruce was first observed on the slopes of Shefford Mountain, near Granby, P.Q. This is one of several monadnocks, of volcanic origin, found in the St. Lawrence valley near Montreal. On other such monadnocks found farther to the north, such as Mount Royal, near Montreal, and St. Hilaire Mountain, near St. Hyacinthe, P.Q., no red spruce was found, as was ascertained by previous observations. It is also absent on Yamaska Mountain, only 10 miles to the west of Granby. Near Granby red spruce is found on granitic water-washed glacial till, and does not occur on deep unmodified till near the top of the mountain, nor on the alluvial soil of the surrounding valley. This species is thus just as particular in its site requirements here as it is in the northern part of its range

1 Extracts from a report of an inspection tour through parts of the Eastern Townghips of Quebec and the New England States, September, 1938.

(2) Forest Classification for Canada-W. E. D. Halliday, Dominion Forest Servlce Bull. 89. 
to the north of the St. Lawrence river. Only 30 miles to the east, however, near Magog, P.Q., red spruce was found occupying nearly the same range of sites as it does in New England and in the Adirondacks, and this was also observed on the limits of the Canada Paper Company near Windsor Mills, P.Q., during a visit in 1936. The southern part of the range of red spruce in Canada is thus bordered to the northwest by a zone of scattered distribution of this species confined to the most favourable sites. In approaching the mountains of New Hampshire, red spruce was observed growing high up on their slopes, well within the Boreal Forest Zone. Previous observations on Mt. Washington and on some tops of the White Mountains have shown red spruce occurring well within the subalpine zone also. All this is in marked contrast to the occurrence of this species in the northern part of its range in Canada. Observations made during this trip confirmed former findings about red spruce occupying just as wide a range of sites in southern Quebec as it does in New England, with but a narrow zone bordering the northwest of its southern range, where its site requirements are much more exacting.

\section{IDENTITY}

During my visit to Gale River Experimental Forest, Pierce Bridge, N.H., in 1931, several transition forms between the black spruce and red spruce were observed growing near the headquarters site of this Forest. The area is a gravelly outwash plain, and is situated between a black spruce swamp and some more fertile uplands containing red spruce. Both species have invaded the area since the last fire, and several transition forms occur also. It is my opinion that these transition forms are natural hybrids between black spruce and red spruce, which on this habitat have had ample opportunity to originate and to survive because of the temporarily lessened competition for shade. This question was discussed with Dr. E. J. Schreiner, geneticist of the Northeastern Forest Experiment Station, who was of the opinion that the range of variation of both red and black spruce was much wider than usually accepted, and that these transition forms may well be extreme variants of either species, surviving on this habitat, but not found under more stabilized forest conditions. Detailed progeny tests of these types furnish the only way of definitely proving their hybrid nature. Many foresters are still of the opinion that the red spruce is but an upland variety of black spruce; this was very definitely shown not to be the case here, where markedly different forms are found growing side by side on the same habitat. 